\title{
The Great Recession and the State of American Capitalism
}

\author{
Maria N. Ivanova
}

\begin{abstract}
The spectacular financial crash of 2008 empowered scores of commentators to envision a 'return of the state' that would swing back the Polanyan pendulum from the savage reality of laissez-faire neoliberalism to a more regulated replica of postwar state-led capitalism. Paradoxically at first glance, these hopes failed to materialize. Public policies enacted to tackle the crisis have done little to loosen up the grip of haute finance on the national and the global economies. Moreover, governments have taken it upon themselves to implement even stricter neoliberal policies by introducing various forms of 'austerity'. This paper offers an alternative explanation of the Great Recession as a crisis of accumulation which has multiple dimensions and involves the totality of capitalist social relations. On this reading, economic and political aspects of the crisis are inseparable as the economic crisis represents simultaneously a crisis of the policies and the institutions of the state.
\end{abstract}

The spectacular financial crash of 2007-8 empowered scores of commentators to envision a 'return of the state' that would swing back the Polanyan pendulum from the savage reality of laissez-faire neoliberalism to a more regulated replica of postwar state-led capitalism. Paradoxically at first glance, these hopes failed to materialize. Public policies enacted to tackle the crisis have done little to loosen up the grip of haute finance on the national and global economy. Moreover, governments have taken it upon themselves to implement even stricter neoliberal policies by introducing various forms of austerity. Accounts of the crisis and proposals for its resolution grounded in the conception of the state and capital (or 'states and markets' in mainstream parlance) as separate and independent entities have been remarkably unable to make sense of these developments.

This essay offers an alternative explanation of the Great Recession as a crisis of accumulation which has multiple dimensions and involves the totality of capitalist social relations. On this reading, economic and political aspects of the crisis are inseparable as the economic crisis represents simultaneously a crisis of the policies and the institutions of the 
state. The causes of the crisis set the parameters of the resolution that followed. Therefore, understanding the former is an indispensable condition for gaining insight into the latter.

My analysis explores the particular case of the United States (US) and is informed by the understanding that the study of this country's development trajectory is of enormous importance for understanding not only the past and present of capitalism but also its future. For, as Marx observed, while violent outbreaks typically occur at the extremities of the bourgeois body, the basis for social change is always laid in its heart (Marx \& Engels, 1975: 134-5).

\section{The Peculiarity of the American Case}

The uniqueness of American experience has been noted by many, often along the lines of Miliband's (1983: 61) observation that

the capitalist class has very seldom enjoyed anything like full hegemony in economic, social, political and cultural terms. One major capitalist country where it has come nearest to such hegemony is the United States - the prime example in the capitalist world of a society where business has not had to share power with an entrenched aristocracy, and where it has also been able to avoid the emergence of a serious political challenge by organized labour.

From its very beginning, the American state represented an economic enterprise brought into being with the direct intervention of the capitalist class. As Charles Beard's pioneering work demonstrates, the overwhelming majority of those who drafted and ratified the Constitution of the US were 'immediately, directly, and personally interested in, and derived economic advantages from, the establishment of the new system' (Beard, 1962 [1913]: 324). These individuals - predominantly lawyers by profession - mostly represented four groups of private property interests which had been adversely affected under the Articles of Confederation: money, public securities, manufactures, and trade and shipping.

Second, multiple variants of a 'businesscrat' - 'a twentieth-century breed of businessman who spends a significant part of his life working as a government bureaucrat' 
(Galambos, 1966: 205, footnote 3) - have played a direct role in the design and execution of government policies. In the recent decades of 'financialization', the historically specific form of this government-business nexus has been epitomized by the proverbial revolving door between Washington and Wall Street. To name a few examples, Robert Rubin served as Treasury Secretary under Bill Clinton half-way between being co-chairman of Goldman Sachs and chairman of Citigroup's executive committee. Henry Paulson, Treasury Secretary under George W. Bush, was former CEO of Goldman Sachs. Alan Greenspan, the second longest-serving chairman of the Board of the Federal Reserve (Fed) later became a consultant to Pimco, a global investment management firm that operates the world's biggest bond fund. Such intimate government-business connections have been multiplied many times over at the lower levels of the government administration and bureaucracy (Johnson, 2009: 50).

Third, the romantic vision of the heroic lone entrepreneur as the source and driver of American economic dynamism is nothing but a figment of petty bourgeois folklore. In actuality, the American economic enterprise has been dominated by big business since its earliest stages. For example, in 1816, the 10 largest banks and 10 largest insurance companies in New York were linked into one network. In 1836, the 10 largest banks owned 70 percent of the bank assets in New York City and 40 percent of the bank assets in the entire state. Similarly, by 1845, a group of eighty men, known as the Boston Associates, controlled 20 percent of the nationwide textile industry. Seventeen of those men served as directors of Boston banks that owned 40 percent of the city's banking capital (Domhoff, 2005: 22-3). In sum, big American businesses have always been owned and controlled by groups of wealthy individuals who share common economic interests and social ties. The corporations, banks, and agribusinesses owned by these individuals form a corporate 
community which has the power to shape the policies of the federal government on matters concerning the income, employment, and well-being of all Americans (Domhoff, 2005: xi, 21ff). As summed up by a business insider:

A bighly complex and largely discrete set of laws and exemptions from laws has been put in place by those in the uppermost reaches of the U.S. financial system. It allows them to protect and increase their wealth and significantly affect the U.S. political and legislative processes. They have real power and real wealth. Ordinary citizens in the bottom 99.9\% are largely not aware of these systems, do not understand how they work, are unlikely to participate in them, and have little likelihood of entering the top $0.5 \%$, much less the top 0.1\%. (Anonymous, 2011)

Debates about some purported autonomy of the state ring particularly hollow in the American case where the capitalist class has enjoyed such an immediate, powerful grip on the state machinery. Yet, we should be cautious not to confuse the State with the government (administration and bureaucracy). Arguably, the US comes closer to the ideal type' of a class project more than any other state at any point of time. However, in order to grasp the peculiarity of this project and the particular mode in which the State as an 'organic fusion of political and civil society' (Gramsci, 1971) has been not less organically fused with capital, one should begin with an inquiry into capital as a social relation and not as individual capitals or fractions of capital, for that matter. Therefore, focusing on the fact that the gentlemen of high finance and leading captains of industry have typically penetrated the upper ranks of government, and thus immediately dominated policy, legislation, and politics, would not be the right point of departure for a study of class hegemony in the US as such a line of inquiry would provide relatively little intelligence as to how this hegemony has been actually sustained. If one accepts Marx's emphasis on capital as a social relation of production, one should first look at the domain where this relation arises and organically takes hold - the social and material world of production.

\section{Capital, the State, and the Eternal Dream of a Regulated Society}


As long as the class-state exists, the regulated society cannot exists, other than metaphorically - that is, only in the sense that the class-state, too, is a regulated society... The confusing of class-state with regulated society is typical of the middle classes and petty intellectuals, who would be delighted with any form of regularization that prevented intense struggles and violent change; it is a typically reactionary and regressive conception (Gramsci, 2011, Vol. III: 11).

Gramsci understood full well that the starting point for the analysis of the capitalist state should be the capitalist society (the so-called civil society) and not the state in general, or the state as a separate and independent entity. For the civil society is an integral part of the state, 'indeed is the State itself (Gramsci, 1971: 261). While a distinction between them can be made for methodological purposes, in concrete historical life, political society and civil society are a single entity' (Gramsci, 2011, Vol. II: 182). Gramsci further insisted that the civil society is inseparable from the economic structure 'properly defined'. That is, social relations should not be seen as external to, or independent of, the process of material production as they ultimately derive from it. This organic continuity of economy, society, and the state follows from the very nature of capitalist production which is both material and social, being simultaneously the production of use values and of value, that is, of social relations (Clarke, 1977). Attempts to autonomize the economy, society, or the state forcibly separate the forces of production from the social relations of production, on the one hand, and the latter from the relations of exchange and distribution, on the other. It is important to understand first, what makes this separation at all possible and, second, what is the reason for it.

In Marx’s analysis, production, circulation (exchange), consumption, and distribution represent distinct, but inseparable, instances in the process of valorization of capital. The exploitative class relation between labor and capital is constituted in production. This relation, however, does not disappear in exchange and distribution; neither does it become more 'harmonious'; it rather takes different, 'fantastic' (in Marx's words), forms. The 
omnipresence of class domination in the capitalist society is obfuscated by the fact that some of its forms are mediated through the 'free' market where commodity exchange (including the purchase and sale of labor power) takes place. The antagonistic character of the capitalist relations of production dissolves itself into the formal 'equality' of the market place, complemented by the democratic 'freedoms' and 'rights' of the 'taxpayers'. The state, which is distinct but inseparable from capital as it represents its political form, plays a crucial role in this process: it is continuously engaged in maintaining the conditions that facilitate exchange (for example, by supplying proper regulatory and legislative framework), while upholding the principles of freedom and equality. In the course of this process, the struggle over the production of surplus value is reconstituted as a distributional conflict which can be periodically cured by a 'fairer' distribution of income via changes in government spending, taxation, and access to credit. This feeds the illusion that economic equality can be achieved through proper legislation and policies. Ultimately, 'so long as politics can be confined to the sphere of circulation and separated from the 'economic' spheres of production, liberalism has achieved its object' (Holloway \& Picciotto, 1977: 90). An idiosyncratic culmination of this type of liberalism is epitomized in the so-called 'states-and-markets' view of (international) political economy where the sphere of production (let alone exploitation and class domination) has all but disappeared, while the most pressing social problems can be solved with proven policy tools, such as government intervention in 'the market' to cure 'market failures', more government spending, regulation of finance, etc. However, the fundamental problems of capitalism - its so-called contradictions - arise not from the lack of regulation, individual greed or the anarchy of the market, not even from the maldistribution of income, which is only a symptom rather than the disease, but from the capital relation itself. Thus, 
even if capital could 'organise' itself through the state, the basic contradiction of capital accumulation would remain — the fact that the pursuit of surplus value implies the tendential destruction or elimination of the basis of surplus value production - the productive worker (Holloway \& Picciotto, 1977: 95).

To understand the evolution of capitalism, it is essential to inquire into the historically specific forms that this destruction of the productive worker takes.

\section{Capitalism and Crisis: How and Why the Great Recession Was Different}

The Great Recession has evoked numerous comparisons with the two deepest structural crises of the twentieth century - the Great Depression of the 1930s and the crisis of the Fordist model in the 1970s. This section attempts to draw some parallels between the three crises while seeking to highlight the unique character of the most recent one.

The Great Recession has often been labeled as the most severe economic crisis since the Great Depression. Are there any similarities between these two events apart from their severity? Both were crises of overaccumulation but this fact, by itself, does not tell us much as all crises of capitalism have, in one form or another, something to do with overaccumulation. The latter tendency arises from the basic operation of the capitalist mode of production whose primary purpose is the production of surplus value, that is, profit. If profits are continuously reinvested, on the one hand, the rate of accumulation soon outruns the rate of profit. On the other hand, the production of surplus value expands at a compound rate, that is, it generates an exponentially growing surplus that needs to be further reinvested. Overaccumulation is the natural outcome of this process. In most general terms, it can be described as the formation of surplus capital relative to reinvestment opportunities. 
More specifically, overaccumulation can take different forms including overinvestment, overproduction, falling profit rates, the emergence of idle production capacity, unemployment, and financial speculation.

The underlying cause of the Great Depression was overinvestment relative to consumer demand against the backdrop of labor abundance and low wages that ultimately drove the economy into an underconsumption trap; hence the depth, length, and severity of the slump (Devine, 1983; 1994). Overinvestment and overproduction also played a role in the run-up to the Great Recession. On a global scale, decades of overinvestment in exportoriented countries have created massive overcapacity and excess supply in manufacturing and industry thereby putting severe pressure on profit rates and prices (Brenner, 2009; McNally, 2009). In the US, the Great Recession was preceded by a massive wave of overinvestment in commercial and residential construction, not to be confused with a general investment boom. The latter occurrence has long become a thing of the past for the US economy as the process of deepening financialization has been accompanied by a general slowdown of capital accumulation (Crotty, 2005; Orhangazi, 2008). The recent overinvestment in construction was more akin to 'capital switching' (Harvey, 1986; Christophers, 2011) - the capital's attempt to dispose of a progressively growing surplus by transferring resources from production proper into built environment for production and consumption. Urbanization represents a special case of this phenomenon.

From their inception, cities have arisen through geographical and social concentrations of a surplus product. Urbanization has always been, therefore, a class phenomenon, since surpluses are extracted from somewhere and from somebody, while the control over their disbursement typically lies in a few hands (Harvey, 2008: 24).

Both urbanization and financialization derive from the above described basic dynamic of the capital accumulation process that is bound to generate an ever rising surplus. Investment in 
construction and/or (fantastic) financial instruments at first alleviates the problem as it freezes exchangeable wealth in a way that 'creates no direct equivalent and therefore devours it, for the moment, without replacement' (Marx, 1993 [1939]: 121). In time, however, both types of investment contribute to the problem of the rising surplus. Housing construction boosts the demand for a variety of housing-related goods and services, while the diversion of a rising share of profits into financial activities not only delays profitability crises, but also maximizes profits by raising consumption capacity. The latter purpose became paramount under neoliberal capitalism which has been characterized by a growing gap between surplus and necessary labor, that is, between profits and wages.

The Fordist crisis of the 1970s and the Great Recession are similar in that they signified the breakdown of the underlying accumulation regime. Politically, this breakdown announced itself as fiscal crisis of the state caused by a surge in expenditure relative to revenue as a result of the mounting claims on the state budget. A brief inquiry into the factors that underlay the birth of Big Government capitalism can shed light as to why the breakdown of the existing accumulation regime inevitably manifests itself as an implosion of the fiscal structure of the state.

In the last three decades of the nineteenth century, the US economy experienced an unprecedented rise in the concentration of capital, manifested in a dramatic increase in the size of the average enterprise in the capital-intensive industries. For example, between 1870 and 1900, the number of iron and steel firms declined from 808 to 669, while the number of people employed more than tripled, output of iron and steel increased from 3.2 to 29.5 million tons, and capital invested rose almost 5-fold, from $\$ 121$ million in 1870 to $\$ 590$ million in 1900 (Heilbroner \& Singer, 1999: 177). In the 1890s, the US entered one of the deepest depressions in its history. Its underlying cause was no other than the infamous 
falling rate of profit resulting from the rising organic composition of capital. Empirically, the problem presented itself as a tendential rise in the overhead costs: the growing share of fixed costs in the total cost structure made profitability critically dependant on the maintenance of high and rising production and sales volumes. This, in turn, unleashed a fierce struggle for market shares, cutthroat competition, and, ultimately, attempts to obtain control over market movements through the establishment of cartels, pools, and trusts.

A powerful check on the tyranny of overhead costs was provided via three main channels. First, at the level of industry, the combination of Fordist automation and the Taylorist management of time led to huge increases in productivity and sped up the turnover of capital. Second, the so-called capital-labor compromise ensured that rising productivity was matched by incremental wage increases thereby providing the material basis of working class consumerism, which was 'scientifically managed' by a comprehensive system of commercial propaganda (Ivanova, 2011). Third, the postwar capitalist state assumed an active role in raising profitability in the capital-intensive sectors of the economy by socializing a share of the production costs. In time, profitability in these sectors came to depend heavily on state expenditure on physical and human capital. In particular, the latter type of expenditure served a two-fold purpose: on the one hand, it relieved capital from the need to carry the full cost of the maintenance of labor power; on the other hand, state expenditure on education and social welfare served to reinforce the popular legitimacy of the existing order. In the early stages of this process, state expenditure expanded social capital thereby increasing productivity and income and, correspondingly, the tax base. Thus, up to a certain point and to a certain extent state spending was self-financing. In time, however, as a growing share of capital costs were socialized, the expenditure rose out of proportion to productivity and it became increasingly difficult for the state to finance its activities from the 
“growth dividend" indirectly produced from outlays on social capital' (O’Connor, 1973: 42). O'Connor's (1973) conclusion remains as prescient today as it was then: the fiscal crisis of the state arises out of the progressive socialization of costs and private appropriation of profits which creates a tendency for expenditure to increase more rapidly than revenue. This underlying problem is further aggravated by the private appropriation of state power for particularistic ends.

What sets apart the Great Recession from all other crises in post-Depression American history is that the officially announced recovery from June 2009 on marked anything but a return to prosperity for the majority of the populace. Record corporate profits in the last two quarters of 2010 did not translate into productive investment. Consumer spending remained subpar - a formidable problem for an economy where consumption comprises over 70 percent of GDP. Even more importantly, the American economy seems to be heading towards a state of perpetual joblessness. More than three years after the official end of the Great Recession, unemployment remains above 8 percent. The main method to tackle the crisis was the disbursement of trillions of dollars in fiscal and monetary stimuli. As the 2011 audit of the Fed revealed, the latter had provided more than $\$ 16$ trillion in total financial assistance to some of the largest financial institutions and corporations in the US and throughout the world.

While the size of the fiscal stimulus paled in comparison to the monetary, the unprecedented socialization of the cost of private blunder and plunder, epitomized in the combination of multiple bailouts, tax subsidies, and business guarantees, along with the collapse of revenue pursuant to the slump, generated exorbitant budget deficits that triggered frantic calls for austerity by conservative forces. Curiously enough, said calls ignored the actual causes of the deficit, not to mention the pre-existing generous system of 
corporate welfare, and chose as their targets instead some of the last remaining artifacts of the already emaciated US welfare state: Social Security, Medicare, and Medicaid. Importantly, the first two of these programs are financed by separate payroll taxes and, although all three are in various degrees underfunded, they could hardly be held responsible for the recent budget deficits. The opportunity to attack these so-called entitlements presented itself with the need to raise the debt ceiling - an ordinary commonplace event that has occurred tens of times over the last several decades.

The fiscal structure of the state, that is, the size and composition of government spending and the distribution of the tax burden, reflects actual social and economic conflicts and is ultimately determined by class struggle. While the state does not analyze its budget in class terms, its '[p]articular expenditures and programs and the budget as a whole are explicable only in terms of power relationships within the private economy' (O'Connor, 1973: 5). President Obama has been all along mindful of these realities as evidenced by the following perceptive remark made in April 2011 when the so-called debt-ceiling debate started to gather steam: '[The Republicans'] vision is less about deficit reduction than it is about changing the basic social compact in America' (Dorning, 2011). It is ironic that whatever the President's own vision might have been, his actions served the same purpose. The turn to austerity has clearly been a bipartisan issue, with the differences between the two parties being tactical rather than strategic. Significantly, it was the Obama administration's first budget for the fiscal year 2010 beginning on 1 October 2009 that marked the decisive turn toward austerity.

The 2010 budget made the bank bailouts a component of government expenditure by including a contingency for $\$ 750$ billion in new aid to the financial industry on top of the $\$ 700$ billion rescue package approved by Congress in October 2008. The net cost to 
taxpayers was estimated at 'only' $\$ 250$ billion by the budget office because of the anticipation that some of the money expended on 'additional financial stabilization efforts' would be eventually recouped (Runningen \& Faler, 2009). Significantly, the sum of the initially budgeted 2010 individual income taxes $(\$ 1,081$ billion) and corporate income taxes $(\$ 249$ billion) fell short of covering the gigantic $\$ 1.45$ trillion handout to the financial system. If we add to that amount total defense spending along with the various supplemental budgets ( $\$ 739.5$ billion) and the interest on the staggering public debt ( $\$ 178$ billion), we arrive at $\$ 2.367,5$ trillion - an amount that would absorb almost all initially budgeted fiscal revenue of $\$ 2.428$ trillion (Office of Management and Budget, 2009). Under the coveted by the Republicans balanced-budget rule, there would have been no money left for anything. Despite its formidable size ( $\$ 3.55$ trillion), the first Obama budget represented 'a mammoth austerity program' and 'the most drastic curtailment in public spending in American bistory' (Chossudovsky, 2009).

Fast forward to August 2011. After an excruciating political spectacle an agreement was reached to raise the debt ceiling by $\$ 2.7$ trillion in two stages: $\$ 1$ trillion immediately and $\$ 1.7$ trillion in the following four months. The increase was to be matched by spending cuts over the next ten years. The first $\$ 1$ trillion included already agreed upon spending cuts mainly in the non-entitlement domestic programs, such as education, housing, transportation, and the environment. $\$ 25$ billion of spending cuts were planned for fiscal year 2012, and $\$ 47$ billion for fiscal year 2013 with rising amounts thereafter. If no additional agreement is reached about the remaining $\$ 1.7$ trillion to $\$ 1.8$ trillion in spending cuts, there will be an across-the-board spending cut in both domestic social programs and the military starting in 2013. 
Beyond a shadow of a doubt, the gradual dismantling or significant curtailment of social spending represents a prime target of deficit-reduction efforts. Yet, one should be cautious not to conceive of the debt-ceiling charade as of a purely distributional conflict. The fundamental causes for the overhaul of the fiscal structure lie deeper than that, in the esoteric world of production of value. The reorientation of the fiscal structure of the state away from social spending should be seen as part of the larger project to universalize and consolidate a new framework (regime) of capital accumulation characterized by novel, historically specific forms of valorization of capital and realization of surplus value. The state does not create new conditions of capitalist development; it only gives them an institutional form after they have already arisen and organically taken hold in the social and material world of production.

\section{The Brave New World of Work}

[T] he American phenomenon ... is... the biggest collective effort to date to create, with unprecedented speed, and with a consciousness of purpose unmatched in history, a new type of worker and of man. The expression 'consciousness of purpose' might appear humorous to say the least to anyone who recalls Taylor's phrase about the 'trained gorilla'. Taylor is in fact expressing with brutal cynicism the purpose of American society developing in the worker to the highest degree automatic and mechanical attitudes, breaking up the old psychophysical nexus of qualified professional work, which demands a certain active participation of intelligence, fantasy and initiative on the part of the worker and reducing productive operations exclusively to the mechanical, physical aspect (Gramsci, 1971: 302).

Gramsci has been blamed for idealizing the 'new man' of the Fordist-Taylorist factory (e.g. Ghosh, 2001). But such critiques are not fully justified. Gramsci's intense preoccupation with the collective subject of the industrial plant was driven by the belief that in the course of its evolution, capitalism itself engenders the condition that will ultimately destroy it. The 'new man' would eventually become the agent of social change. This view, however, underestimated the resilience and versatility of the Fordist-Taylorist production paradigm, its 
ability to transcend the confines of the industrial plant and form the organizational core, first, of the services-based, and, later, of the knowledge-based economy. Advances in technology and scientific management of the labor process provided the essential means through which class dominance has continuously reasserted itself in different socioeconomic contexts.

While new technology engenders new workplace practices, such as the modern-day 'reengineering', 'enterprise resource planning', and, most recently, 'crowdsourcing' and 'cognitive piecework', their invariable purpose remains to automate, simplify, integrate, and speed up business processes, thereby imposing upon them the standardization, measurement, monitoring and control of the old industrial mass production plant. Thus, '[d] espite their heavy reliance on advanced digital technologies, [the practices of the "new economy”] remain profoundly “old economy” phenomena' (Head: 2005, 5).

Due to advances in computer technology and software, the increased access to personal computers, and the virtual migration of labor markets into cyber space, the capital relation is acquiring new forms, radically different from those that prevailed under industrial capitalism. These new forms are not less, but arguably even more, exploitative than the old ones. The digital age has created its own assembly line along with a digital proletariat toiling under conditions closely resembling those of the sweatshops in the 'emerging markets'. Said conditions impart an undue appeal to the old Fordist-Taylorist production plant. Nothing exemplifies said conditions better than the phenomenon of the so-called crowdsourcing and its application to platforms for online work, such as the Amazon's Mechanical Turk.

According to Howe's (2006a) definition, crowdsourcing represents

the act of a company or institution taking a function once performed by employees and outsourcing it to an undefined (and generally large) network of people in the form of an open call. This can take the form of peer-production (when the job is performed collaboratively), but is also often undertaken by sole 
individuals. The crucial prerequisite is the use of the open call format and the large network of potential laborers.

Crowd labor occurs under circumstances that are impossible to fit into the traditional framework of the wage relation. There is no physical work site or an employer-employee relation. In fact, the laborer does not qualify as an employee. He or she is an independent contractor than can be used at will. There is no wage, but a 'reward'. The crowd employer does not have any obligations to the crowd worker, not even that of paying him. The granting of the 'reward' is conditional on crowd employer's satisfaction and, ultimately, on his or her willingness to pay.

In 2005, the online retailer Amazon.com established the largest platform for online work called the Mechanical Turk (MTurk), which has since become the first stop for firms and individuals (called requesters) seeking cheap, on demand crowd laborers (called providers). Requesters post to the website 'Human Intelligence Tasks' (HITs), specifying the 'reward' and the time for the completion of the task. The providers (colloquially called turkers) decide whether or not to accept the task. Once accepted, the task has to be completed within the designated time and submitted to the website. The Amazon's Participation Agreement contains a built-in, mandatory satisfaction clause which gives the requester the right to reject any submitted HITs without paying the provider, without giving a justification, and without forfeiting possession or ownership of the work (Felstiner, 2011: 120). Crowd laborers perform their tasks under fairly brutal conditions. According to the Agreement, providers agree, among other things, 'not to use robots, scripts, or other automated methods to complete the Services', to furnish the requester with 'any information reasonably requested', and to agree that they will not be entitled to any employee benefits, and will not be eligible to recover worker's compensation if injured (quoted in Ibid: 121). Violation of the various terms of use imposed by Amazon upon registration may entail the 
cancelation of the provider's account including the forfeiture of any earnings left in said account.

These substandard working conditions pale in comparison to the nature of work. Cognitive piecework includes tasks, such as image tagging, categorizing products, finding and copying information from websites, while examples of more 'sophisticated' tasks comprise audio transcription, providing survey feedback, or writing a short review of a website or product. In Howe's (2006b) words,

[The Mechanical Turk] gives us a snapshot of a depressing future in which legions of click-slaves toil away at identifying duplicate $W$ eb pages for less than minimum wage. Amazon says it hit on the idea for Mechanical Turk, when it realized that there were some tasks that even the smartest computers couldn't perform. I've got an alternate theory. Maybe the computers just didn't want to.

The number of MTurk participants is estimated at about 200,000. Some of the simple HITs, such as tagging photographs or identifying relevant phrases, pay as little as $\$ 0.01$ per task. The rewards are in general tiny: 25 percent of the HITs have a price tag of just $\$ 0.01,70$ percent have a reward of $\$ 0.05$ or less, and 90 percent pay less than $\$ 0.10$ (Ipeirotis, 2010b). Turkers earn on average about $\$ 1.20$ per hour which is well below the federal minimum wage of $\$ 7.25$ per hour. Who would work for so little money? Initially, Amazon.com paid in cash only workers with bank accounts in the US. Workers from other countries could participate but they were compensated with Amazon gift cards. Correspondingly, the overwhelming majority of turkers were US residents. In 2007, Amazon allowed workers in India to be paid in the local currency which led to significant changes in the demographics of the MTurk. A survey conducted by Ross et al. (2010) reveals that while the majority of turkers are still US residents (57 percent), 32 percent are from India, while the rest reside in a variety of countries. According to the same source, 31 percent of turkers are unemployed and another 31 percent have part-time jobs; 12 percent have high-school diplomas, 21 percent some college, 8 percent an Associates degree, 42 percent a Bachelor's, 
and 16 percent an advance degree. Another survey confirms that while the educational level of US turkers is higher, their income level is lower, than that of the general population (Ipeirotis, 2010a). 13.8 percent of the US and 28 percent of Indian participants use the M'Turk as a primary source of income (for paying bills, gas, groceries, etc.). Respectively, 61.5 and 37 percent use it as a secondary source of income (for hobbies, gadgets, going out, etc.). About 70 percent of the American and 60 percent of Indian respondents see turking as a 'fruitful' way to spend their time and as a money-earning alternative to watching TV (Ibid).

In sum, on the one hand, we have desperate, hard-pressed people working the mindnumbing HITs out of bare necessity. As one turker confesses,

I don't know about where you live, but around here even McDonald's and W almart are NOT hiring. I have a degree in accounting and cannot find a real job, so to keep myself off of the street I work 60 bours or more a week here on mTurk just to make \$150_\$200. That is far below minimum wage, but it makes the difference between making my rent and living in a tent. (Quoted in Felstiner, 2011: 124)

On the other hand, respectively 32 and 40 percent of US respondents in Ipeirotis' (2010a) survey give as a reason for participation, among others, killing time or that the tasks are fun. The overarching framework is that of work encroaching upon free, personal time and the blurring of the boundaries between the two.

The evolution of work can acquire its full meaning only when analyzed in the context of broader social change. Staggering inequalities in the distribution of income and wealth have long been recognized as a salient feature of US capitalism. Often overlooked is that social inequality was aggravated but not created by the overhaul of the fiscal structure of the state that has been underway since the early years of Reaganomics. Deepening inequality has been part and parcel of the ongoing structural transformation of American capitalism and a byproduct of the 'changing mix of industries in the economy' (Mishel, Bernstein \& Shierholz, 2009: 183-5). Thus, the shift from goods-producing to the services-based economy brought about the displacement of well-paying, union jobs with benefits by low- 
paying, flexible, no-benefit service jobs. The ongoing shift to the knowledge-based economy is the next stage in this 'natural' progression, introducing novel ways of extraction and realization of surplus value, that is, new forms of destruction of the productive worker.

\section{The Way Forward}

American and global capitalism is undergoing a systemic crisis whose solution cannot be found within the present framework but requires radical changes to the existing accumulation regime. These changes are already underway and seemingly unstoppable. The reason why government's fine-tuning of the economy through monetary and fiscal policies is no longer doing its magic is that such policies have become thoroughly inadequate in the new socio-economic context. Even most unorthodox monetary policies, such as those enacted by the Fed under Ben Bernanke, can only have a temporary stabilization-like effect. Fiscal policy has become unorthodox in its own right: notwithstanding their formidable size, the last three Great Recession budgets could hardly qualify as expansionary in the sense of Keynesian demand management as they were not structured in a way that could stimulate domestic investment and consumer demand. But this should not imply that (post-)industrial capitalism and its consumer society could be kept on life support by more savvy policies along Keynesian lines. Correspondingly, the fiscal structure of the state, created to support this type of capitalism, is now being shattered, turned upside down, because its revenue structure has become inadequate to finance the growing claims on the state budget by the system of corporate welfare, the permanent war economy, and the servicing of the mounting debt while preserving even partially the 'entitlements' of the welfare state. 
The steady decline of the share of taxes paid by business exemplifies an important aspect of the problem. The share of corporate income taxes in total revenue averaged 28 percent in the 1950s, 21 percent in the 1960s, and about 10 percent since the 1980s. According to the Obama Administration 2012 budget proposal, this share was 8.8 percent in 2010 and is projected to be 9.1 percent in 2011 (Office of Management and Budget, 2010). Although the top corporate tax rate in the US is 35 percent, one of the highest in the world, some of the biggest corporations manage to avoid paying taxes altogether. For example, the nation's largest corporation General Electric did exceedingly well in 2010 reporting worldwide profits of $\$ 14.2$ billion, $\$ 5.1$ billion of which came from its operations in the US. Instead of paying any taxes in the US, GE claimed a tax benefit of $\$ 3.2$ billion. This windfall comes on the top of a decade of spectacularly rising profits. Since 2002, the company has eliminated a fifth of its work force in the US while increasing overseas employment. This boosted its offshore profits over the period from $\$ 15$ billion to $\$ 92$ billion (Kocieniewski, 2011). Capital does no longer want to pay its 'fair' share because it does not have to. There is nobody to compel it to and nothing to be gained from a 'compromise'. The notion of a 'national' economy is becoming increasingly obsolete in the world of globalized production. Correspondingly, the fiscal structure of the state is being brought into conformity with the social relations already established in the private economy.

Bar some miraculous technological developments that could possibly reverse some of the tendencies underway, capital's most likely way forward is to bring the exploitation of labor to new heights through innovative productivist and organizational practices, such as those employed on the above discussed MTurk platform. The American economy and society is the laboratory of the future where these new forms are now being tested, while the state plays a crucial role in creating the conditions that would ensure their acceptance and 
universalization. The latter include as thorough as possible dismantling of social safety nets and all forms of social and institutional support that shielded labor from a complete exposure to the vagaries of capital. Thus, the massive effort to curtail state expenditure is not ultimately driven by the unsustainability of the US debt and deficit, however formidable they might be, but by the attempt to speed up the transformation of the 'social compact' along the requirements of the new forms of work and production. This, admittedly, quite disheartening reality has been systematically ignored even by most progressive writers who have been hard at work to prove that the debt is not that large or that running deficits during a recession is the right thing to do. But such arguments are beside the point as they tend to reify the postwar welfare state as an institutional arrangement that could be inserted into different economic and social contexts. In actuality, said welfare state represented a historically specific form of state-society complex that arose organically from a particular mode of accumulation and will eventually die with it or, at the very least, undergo substantial transformation. The underlying purpose of the capitalist class state is not to maximize welfare for all; therefore, all proposals for how to do this in a more efficient manner remain charmingly naïve at best.

\section{Conclusion}

This article argues that the Great Recession has unleashed an attempt of capital as a social relation to reorganize itself through the state in a way that would ensure its reproduction on radically different and more exploitative terms. The destruction of the productive worker has assumed new forms; Gramsci's 'new man' is being miraculously replicated by 'the crowd'. While the ultimate outcome of this enterprise remains to be seen, in the absence of an equal force to counter it, its success seems by default assured. That 'success' would mark a radical 
and irreversible departure from the postwar, 'hegemonic', type of class dominance with all its heart-warming paraphernalia, such as the middle class, homeownership, the rewards of hard work, social mobility, and the American dream. At that point, the ruling class would have 'lost its consensus', it would be 'no longer "leading" but only "dominant", exercising coercive force alone, this means precisely that the great masses have become detached from their traditional ideologies, and no longer believe what they used to believe previously' (Gramsci, 1971: 275-6). Thus, "hegemony becomes "saturated" - it is dissolved not from below, but from within - 'because the bourgeoisie is not ultimately a universal class but, in an orthodox Marxist sense, a selfish one which inevitably returns to "the conception of the State as pure [repressive] force"” (Ghosh, 2001: 7).

\section{References}

Anonymous. (2011) 'An Investment Manager's View on the Top 1\%', July, Who Rules America, available at

http://sociology.ucsc.edu/whorulesamerica/power/investment manager.html, Accessed on 25 July 2011.

Beard, Charles A. (1962 [1913]) An Economic Interpretation of the Constitution of The United States. New York: Macmillan.

Brenner, Robert. (2009) 'What is Good for Goldman Sachs is Good for America: The Origins of the Present Crisis, UC Los Angeles: Center for Social Theory and Comparative 
History. Available at http://escholarship.org/uc/item/0sg0782h. Accessed on 1 July 2010.

Chossudovsky, Michel. (2009) 'America's Fiscal Collapse', Available at http://www.globalresearch.ca/index.php?context $=$ va\&aid $=12517$

Christophers, Brett. (2011) 'Revisiting the Urbanization of Capital', Annals of the Association of American Geographers, DOI:10.1080/00045608.2011.583569

Clarke, Simon. (1977) 'Marxism, Sociology and Poulantzas's Theory of the State', Capital \& Class 1(2): 1-31.

Crotty, James. (2005) 'The Neoliberal Paradox: The Impact of Destructive Product Market Competition and 'Modern' Financial Markets on Nonfinancial Corporation Performance in the Neoliberal Era, in: Gerald Epstein (Ed.) Financialization and the World Economy, Cheltenham, UK: Edward Elgar.

Devine, James D. (1983) 'Underconsumption, Over-Investment and the Origins of the Great Depression', Review of Radical Political Economics 15(1): 1-27.

Devine, James D. (1994) 'The Causes of the 1929-33 Great Collapse: A Marxian Interpretation', Research in Political Economy 14: 119-194.

Domhoff, G. William. (2005) Who Rules America: Power, Politics, and Social Change. $5^{\text {th }}$ Ed. New York: McGraw-Hill.

Dorning, Mike. (2011) 'Obama Sets June Deadline for Deficit-Cut Deal in Challenge to Republicans', Bloomberg News, Available at http://www.bloomberg.com/news/2011-0414/obama-sets-june-deadline-for-deficit-cut-deal-in-challenge-to-republicans.html

Felstiner, Alek. (2011) 'Working the Crowd: Employment and Labor Law in the Crowdsourcing Industry', Berkeley Journal of Employment \& Labor Law 32(1): 101-61.

Galambos, Louis. (1966) Competition \& Cooperation: The Emergence of a National Trade Association. Baltimore, MD: Johns Hopkins Press. 
Ghosh, Peter. (2001) 'Gramscian Hegemony: An Absolutely Historicist Approach', History of European Ideas 27: 1-43.

Gramsci, Antonio. (1971) Selections from the Prison Notebooks, Edited and translated by Quentin Hoare and G. Nowell Smith, New York: International Publishers.

Gramsci, Antonio. (2011) Prison Notebooks, Volume I-III, Edited and translated by Joseph A. Buttigieg, New York: Columbia University Press.

Harvey, David. (1985) The Urbanization of Capital: Studies in the History and Theory of Capitalist Urbanization. Baltimore, MD: The Johns Hopkins University Press.

Harvey, David. (2008) 'The Right to the City', New Left Review 53: 23-40.

Head, Simon. (2005) The New Ruthless Economy: Work and Power in the Digital Age. New York: Oxford University Press.

Heilbroner, Robert L., and Alan Singer. (1999) The Economic Transformation of America: 1600 to the Present. $4^{\text {th }}$ Ed. Wadsworth Publishing.

Holloway, John, and Sol Picciotto. (1977) 'Capital, Crisis and the State', Capital \& Class 1(2): 76-101.

Howe, Jeff. (2006a) ‘Crowdsourcing: A Definition’, 2 June, Crowsourcing Website, Available at http://www.crowdsourcing.com/cs/2006/06/crowdsourcing_a.html, Accessed on 6 May 2011.

Howe, Jeff. (2006b) 'Taking Measure of Mechanical Turk', Crowdsourcing, 3 Novermber, Available at http://www.crowdsourcing.com/cs/2006/11/taking measure .html, Accessed on 5 May 2011.

Ipeirotis, Panos. (2010a) 'Demographics of Mechanical Turk], CeDER-10-01 working paper, New York University. 
Ipeirotis, Panos. (2010b) 'Analyzing the Amazon Mechanical Turk Marketplace', XRDS: Crossroads, The ACM Magazine for Students, 17(2).

Ivanova, Maria N. (2011) 'Consumerism and the Crisis: Wither "the American Dream”?', Critical Sociology 37(3), 2011: 329-350.

Johnson, Simon. (2009) 'The Quiet Coup', The Atlantic Monthly 303 (4): 46-56.

Kocieniewski, David. (2011) 'G.E.'s Strategies Let It Avoid Taxes Altogether', New York Times, 24 March.

Marx, Karl, and Friedrich Engels. (1975) Collected Works, Volume 10. New York: International Publishers.

Marx, Karl. (1993 [1939]) Grundrisse: Foundations of the Critique of Political Economy. London:

Penguin Books.

McNally, David. (2009) 'From Financial Crisis to World Slump: Accumulation, Financialisation and the Global Slowdown', Historical Materialism, 17: 35-83.

Miliband, Ralph. (1983) 'State Power and Class Interests', New Left Review I/138: 57-68.

Mishel, Lawrence, Jared Bernstein, and Heidi Shierholz. (2009) The State of Working America 2008/2009. Ithaca, NY: Cornell University Press.

O'Connor, James (1973) The Fiscal Crisis of the State. New York: St. Martin's Press.

Office of Management and Budget. (2009) A New Era of Responsibility: Renewing America's

Promise. US Government Printing Office: Washington, D.C.

Office of Management and Budget. (2010). Fiscal Year 2012 Budget of the US Government. US

Government Printing Office: Washington, D.C.

Orhangazi, Özgür. (2008) 'Financialisation and Capital Accumulation in the Non-financial Corporate Sector: A Theoretical and Empirical Investigation on the US Economy, 19732003', Cambridge Journal of Economics 32: 863-886. 
Ross, Joel, et al. (2010). 'Who are the Crowdworkers? Shifting Demographics in Amazon Mechanical Turk', Paper presented at the 2010 ACM CHI Conference, Available at http://www.ics.uci.edu/ jwross/pubs/SocialCode-2009-01.pdf, Accessed on 1 September 2011.

Runningen, Roger, and Brian Faler. (2009) 'Obama Budget Has Contingency for More Aid to Banks', Bloomberg News, 26 February, Available at

http://www.bloomberg.com/apps/news?pid=newsarchive\&sid=a9ZpGFQikqp4 